DOI 10.37882/2223-2982.2021.12.08

\title{
ФУНКЦИОНИРОВАНИЕ ЗРИТЕЛЬНЫХ ПРЕДИКАТОВ В ЯКУТСКОМ ЯЗЬКЕ (НА МАТЕРИАЛЕ ПРОИЗВЕДЕНИЯ Н.К. СЕДАЛИЩЕВА-ДЬҮӨГЭ ААНЫСТЫЫРАП «НЬУРГУһУН УОННА ЛООКУУТ»)
}

\section{FUNCTIONING OF VISUAL PERCEPTION PREDICATES IN THE SAKHA LANGUAGE (ON THE MATERIAL OF THE DRAMA "NYURGYHUN UONNA LOOKUUT" BY N.K. SEDALISHCHEV-JYOGE AANYSTYRAP)}

\section{R. Ivanova \\ E. Afanaseva G. Pavlova}

Summary:This article studies the representation of the category of visual perception in the Sakha language in the literary work «Nyurguhun uonna Lookut» by N.K. Sedalishchev-Jyoge Aanystyrap. As a result of the analysis, it was revealed that visual predicates are used to nominate human feelings. This indicates that the inner world of a person, which is difficult for verbalization, somehow resorts to the most understandable for him perceptual experience of the external material world. In this work, the functioning of visual predicates is considered in parallel with the analysis of the text.

Keywords: Sakha language, perception, visual, text, predicate.
Иванова Раиса Петровна

К.филол.н., Политехнический институт (филиал) ФГАОУ ВО «Северо-Восточный федеральный университет им. М.К. Аммосова» в г. Мирном Raissa1@yandex.ru

Афанасьева Евдокия Николаевна К.филол.н, С.н.С., ФГБУН «Институт гуманитарных исследований и проблем малочисленных народов Севера Сибирского отделения Российской академии наук» lukow@mail.ru

Павлова Гералина Германовна Политехнический институт (филиал) ФГАОУ ВО «СевероВосточный федеральный университет им. М.К. Аммосова» в г. Мирном jeon.geralina.ru@mail.ru

Аннотация: В данной статье рассматривается репрезентация категории зрительной перцепции в якутском языке на материале произведения Н.К. Седалищева-Дьүөгэ Ааныстыырап «Ньургуһун уонна Лоокуут». В результате анализа выявлено, что зрительные предикаты используются для номинации чувственной сферы человека. Это свидетельствует о том, что сложный для вербализации внутренний мир человека так или иначе прибегает к наиболее понятному для него перцептивному опыту восприятия внешнего материального мира. В работе функционирование зрительных предикатов рассматривается параллельно с анализом текста.

Ключевые слова: якутский язык, перцепция, зрительное восприятие, текст, предикат.

генде о любви. В якутской культуре мотив популярный; разные одноименные версии драмы также представили другие писатели Суорун Омоллон, Тимофей Сметанин. Постановка входит в репертуар Саха академического драматического театра. Некоторые читатели, воспитанные на европейской классике, находят сходство легенды с историей «Ромео и Джульетты» У. Шекспира. Однако автор выбрал для своих героев счастливую судьбу. Мальчик-работник Локут и дочь хозяев Нюргусун растут вместе и в юношеском возрасте влюбляются друг в друга. Они не ощущают неравенство своего социального положения и не знают о планах взрослых об их будущем. Когда дочь выросла, отец решает выдать дочь замуж за сына богача. Нюргусун, разбитая горем от этой новости, падает в обморок и впадает в летаргический сон. Родители решают, что дочь умерла, и хоронят ее, соорудив по якутским обычаям могильный лабаз 'аранас' высоко между двумя деревьями. Ночью безутешный Локут идёт

Сюжет лирической драмы основан на старинной ле- 
прощаться на могилу любимой, услышав его плачь, Нюргусун просыпается. Испугавшись, Локут убегает. Позже выясняется, что Локут разбудил ее своими прощальными речами и сам того не зная, стал спасителем. Родителям Нюргусун остается подчиниться воле воскресшей дочери и благословить брак с Локутом.

Рассмотрим функционирование перцептивной лексики зрительного восприятия в тексте произведения.

1. Саас кэлэр көтөр үөрдэрэ уөһэнэн айманан ааһалларын, күөрэгэй күөх хонуу үрдүнэн ыллаан дыырыбыныырын чарапчыланан, кыңнайакыңнайа одуулаһаллара. [Весной они разглядывали, как с криками пролетают перелетные птицы в небе, как поет жаворонок над зеленым полем, чуть наклонив головы, прикрывали ладонями глаза от слепящего солниа]. - перевод наш.

В данном фрагменте языкового материала зрительное восприятие репрезентируется посредством глагола одуулаһаллара - взаимн. от одуулаa = 'разглядывать, рассматривать кого-что-л.; всматриваться в кого-что-л., присматриваться к кому-чему-л.'

Лексема номинирует зрительное восприятие с параметром долговременного процесса восприятия, а также качественной характеристикой «смотреть пристально, с удовольствием». Влюбленные герои приветствуют приход весны, всё в их глазах кажется прекрасным, они восхищаются пением жаворонка и всматриваются в каждую деталь пробуждения природы после долгой зимы. Для культуры саха наступление весны является одной из основных ценностей, так как долгая зима, которая длится девять месяцев, делает её самой долгожданной и желанной порой. Приход весны в произведении также символизирует зарождение их первой любви, искренней и наивной.

2. Сайын ийэ кусот иhиттэноболорун батыһыннаран, күөлгэ киллэртиирин саһан кэтииллэрэ. [Летом они наблюдали за тем, как утка ведет своих утят за собой гуськом к озеру].

В вышеприведенном отрывке описывается летний день, главные герои прячутся и поджидают уток, которые с утятами заходят в озеро. Лексема зрительного восприятия кэтииллэрэ - взаимн. от кэтээ = 'ждать, поджидать, наблюдать' обладает как качественными, так и временными характеристиками процесса зрительного восприятия и обозначает длительный процесс целенаправленного наблюдения за кем-либо со стороны. Временной параметр, обозначающий повторяющееся в прошлом действие, содержит также качественную характеристику с положительной коннотацией, которая на уровне подтекста описывает развитие чувств двух влю- бленных, наблюдая за утками с утятами, молодые мечтают о своей собственной семье.

3. Оттон Лоокуут ... эрдини көруннээх төрөлкөй уолан киһи буолбута. [А Локут... стал рослым молодым человеком, имеющим вид мужчины].

Прилагательное со значением зрительного восприятия көрүннээх - взаимн. көрүн= 'имеющий вид; видный' описывает внешний вид Локута, который возмужал и стал выглядеть как настоящий мужчина в рассвете сил. В глазах Ньургуһун нет никого лучше Лоокуута, несмотря на его низкий социальный статус и небогатую семью.

\section{4. Ньургуһун Лоокууттуун сирэй-сирэйдэрин таба көрсубэт буолалларын бэйэлэрэ да билбэккэ ха- алаллара. [Локут и Нюргусун, сами того не зная, иногда не смели смотреть друг другу в глаза].}

Трепетную любовь и истинные чувства героев друг к другу описывает зрительный предикат таба көрсубэт досл. 'они не смотрели друг другу в глаза', взаимн. таба = 'удачно, верно, прочно', көр = 'смотреть, глядеть, видеть что-л... Они так любили и дорожили друг другом, что не смели смотреть в глаза друг другу, стеснялись. Таким образом, зрительный предикат в данном контексте обозначает трепетные чувства героев друг к другу, представляя собой перцептивную метафору.

5. Ньургуһун, субу-субу Лоокуукка иэдэс биэрэ-биэрэ, киһи сүрэбин-быарын курдаттыы кууһан ылыах айылаахтык көссүө хара харахтарынан көрутэлээн кэбиһэрэ. [Часто, отворачивая личо от Локута, Нюргусун игриво посматривала своими кроткими черными глазами, словно хотела обнять всем сердием и душой].

Зрительный предикат көрутэлээ = 'смотреть много раз,' ‘посматривала игриво' номинирует повторяющийся процесс зрительного восприятия, который, на уровне подтекста, описывает бережные, искренние отношения между двумя возлюбленными. Нюргусун игриво посматривала на Лоокуута (көрүтэлээн кэбиһэрэ), будто собиралась броситься к нему в объятия.

6. Булка бардахтарына Ньургуһун Лоокууту кэнниттэн иһэн, этэрбэс маанарыттан кэтэбэр диэри эйэлээхтик көрөн таһаaрара. [Когда шли на охоту, Нюргусун, идя следом за Локутом, мирно рассматривала его с веревок торбасов до затылка].

Как показал анализ фактического материала, предикат зрительного восприятия көр -'смотреть' используется метафорично для описания глубоких искренних чувств героев произведения, их бесконечной и безграничной любви, трепета друг к другу. Также и в вышеприведен- 
ном примере главная героиня Ньургуһун смотрит вслед своему возлюбленному. Она смотрела на возмужавшего Лоокуута уже другими глазами. Сама того не осознавая, Ньургуһун рассматривала Лоокуута с ног до головы. Во время охоты девушка всегда шла за ним, и в этот раз она чувствовала себя как за каменной стеной эйэлээхтик көр - взаимн. эйэлээхтик - нареч. 'мирно, дружно', көр - 'смотреть, глядеть; наблюдать что-л., за чём-л.' досл. 'она мирно рассматривала Локута с ног до головы'.

\section{7. Ол иһэннэрЛоокуутхайдахэрэкэннин хайы һaары} гыннабына, Ньургуһун тугу да билбэтэхкөрбөтөх буолара. [Так они шли, а когда Локут хотел оглянуться к ней назад, Нюргусун делала

\section{вид как-будто ничего не видит и не знает].}

В данном примере предикат зрительного восприятия кэннин хайыһаары - 'оглянуться' и парное прилагательное билбэтэх-көрбөтөх - 'ничего не видевший, не знавший' также описывают теплые и нежные отношения между влюбленными.

В драме представлены все краски чистой первой любви, переданные контекстуальной метафорой на основе предикатов зрительного восприятия: согласие, мир, любование друг другом, переживание трепетных чувств, стеснительность, бережное отношение друг к другу, чувство защищенности рядом друг с другом.

\section{ЛИТЕРАТУРА}

1. Верхотурова Т.Л. Фактор наблюдателя в языке науки. Иркутск: ИГЛУ, 2008. 289с.

2. Кравченко А.В. Язык и восприятие: Когнитивные аспекты языковой категоризации. Иркутск: ИГУ, 2004. 206с.

3. Ньургуһун уонна Лоокуут / Дьүөгэ Ааныстыырап; хомуйан онордулар: А.И. Аржаков уо.д.а. - Дьокуускай : Бичик, 2003. 127 с.

4. Словарь якутского языка https://sakhatyla.ru/

() Иванова Раиса Петровна (Raissa1@yandex.ru), Афанасьева Евдокия Николаевна (lukow@mail.ru),

Павлова Гералина Германовна (jeon.geralina.ru@mail.ru).

Журнал «Современная наука: актуальные проблемы теории и практики»

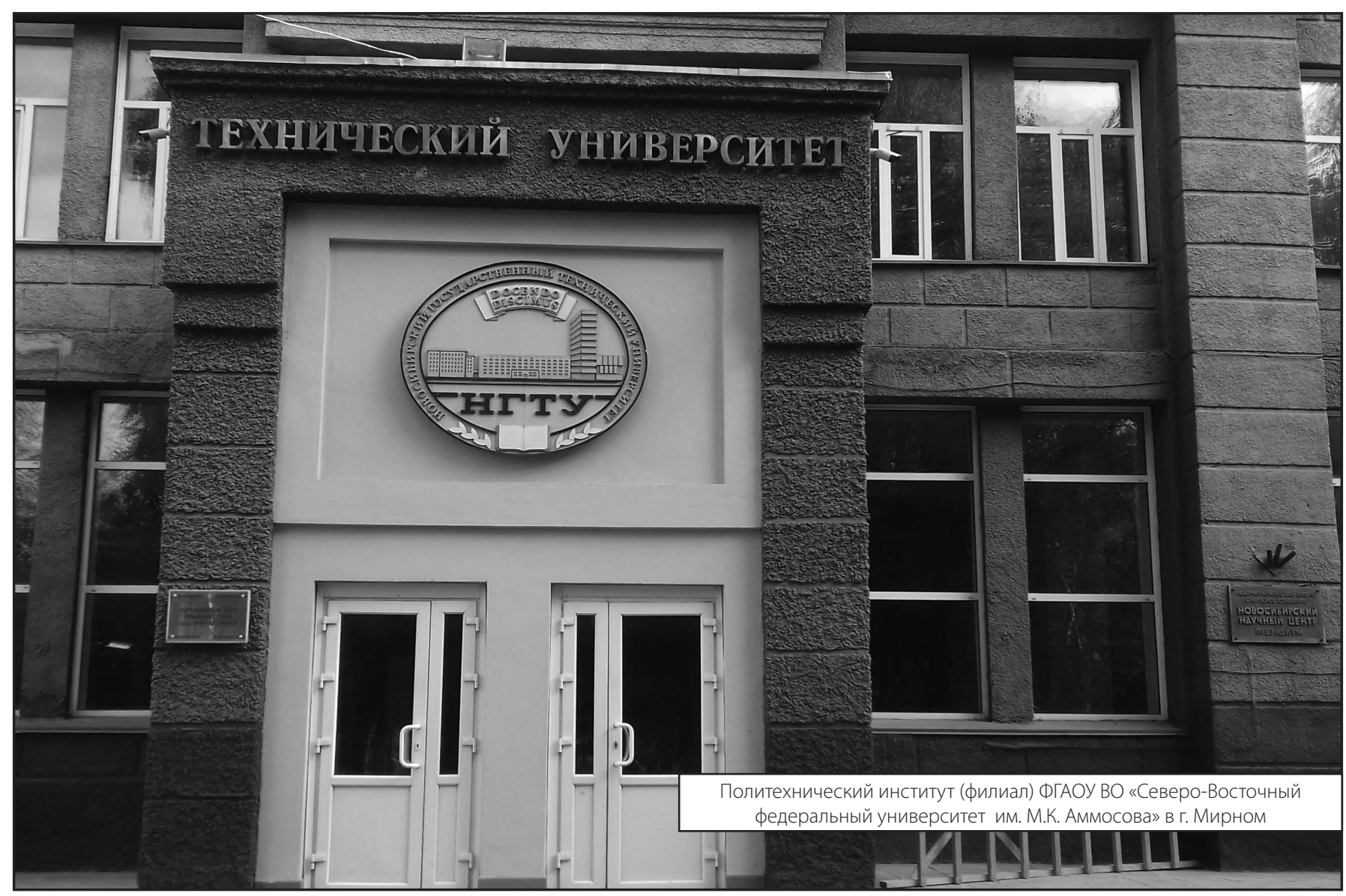

